
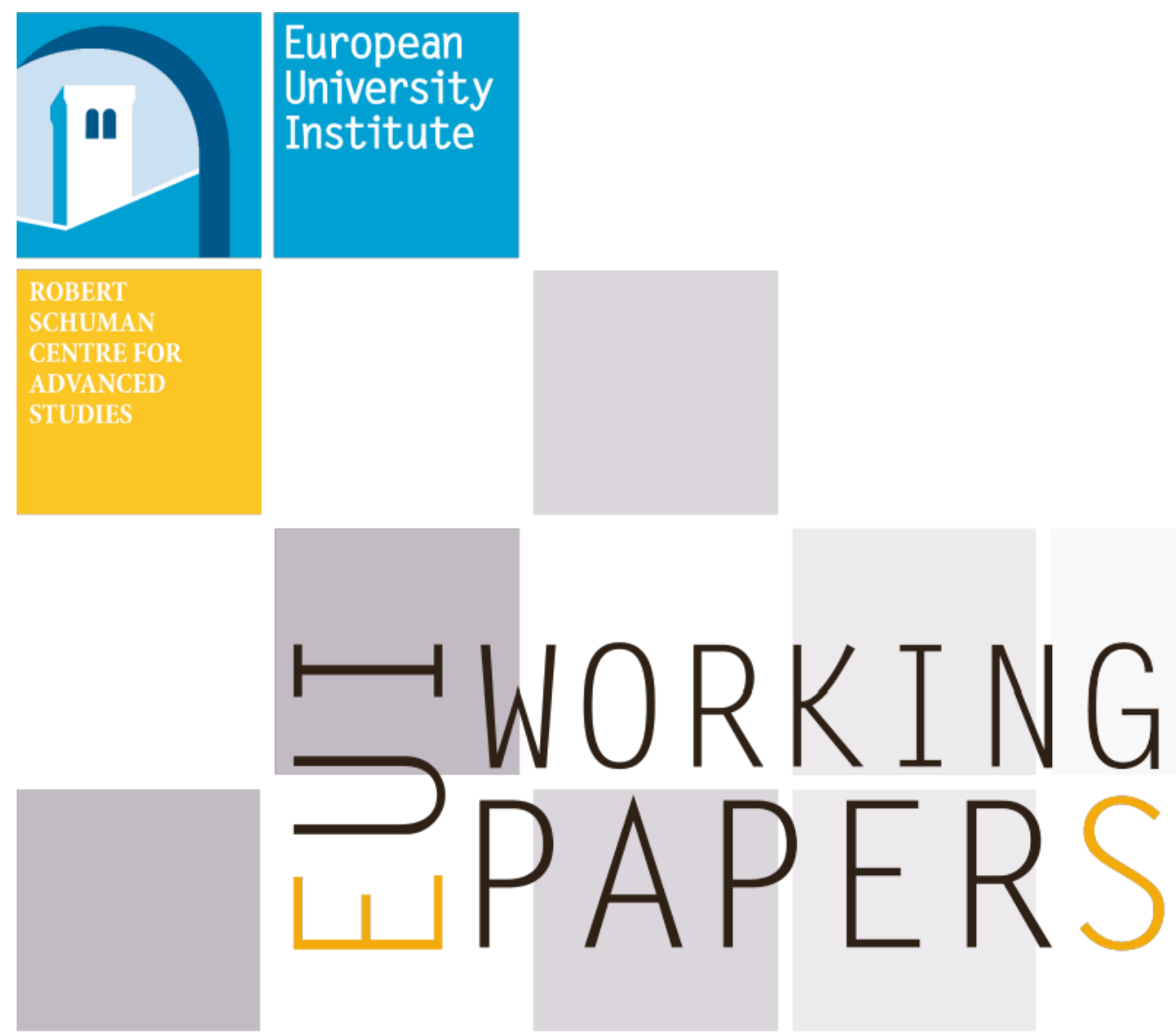

RSCAS 2016/27

Robert Schuman Centre for Advanced Studies Global Governance Programme-217

Controlling Covert Integration in EU Politics

Johan Adriaensen and Evelyn Coremans 
European University Institute

Robert Schuman Centre for Advanced Studies

Global Governance Programme

\section{Controlling Covert Integration in EU Politics}

Johan Adriaensen and Evelyn Coremans

EUI Working Paper RSCAS 2016/27 
This text may be downloaded only for personal research purposes. Additional reproduction for other purposes, whether in hard copies or electronically, requires the consent of the author(s), editor(s). If cited or quoted, reference should be made to the full name of the author(s), editor(s), the title, the working paper, or other series, the year and the publisher.

ISSN 1028-3625

(C) Johan Adriaensen and Evelyn Coremans, 2016

Printed in Italy, April 2016

European University Institute

Badia Fiesolana

I - 50014 San Domenico di Fiesole (FI)

Italy

www.eui.eu/RSCAS/Publications/

www.eui.eu

cadmus.eui.eu 


\section{Robert Schuman Centre for Advanced Studies}

The Robert Schuman Centre for Advanced Studies (RSCAS), created in 1992 and directed by Professor Brigid Laffan, aims to develop inter-disciplinary and comparative research on the major issues facing the process of European integration, European societies and Europe's place in $21^{\text {st }}$ century global politics.

The Centre is home to a large post-doctoral programme and hosts major research programmes, projects and data sets, in addition to a range of working groups and ad hoc initiatives. The research agenda is organised around a set of core themes and is continuously evolving, reflecting the changing agenda of European integration, the expanding membership of the European Union, developments in Europe's neighbourhood and the wider world.

Details of the research of the Centre can be found on: http://www.eui.eu/RSCAS/Research/

Research publications take the form of Working Papers, Policy Papers, and e-books. Most of these are also available on the RSCAS website:

http://www.eui.eu/RSCAS/Publications/

The EUI and the RSCAS are not responsible for the opinions expressed by the author(s).

\section{The Global Governance Programme at the EUI}

The Global Governance Programme is one of the flagship programmes of the Robert Schuman Centre for Advanced Studies at the European University Institute (EUI). It aims to: build a community of outstanding professors and scholars, produce high quality research and, engage with the world of practice through policy dialogue. At the Global Governance Programme, established and early career scholars research, write on and discuss, within and beyond academia, issues of global governance, focussing on four broad and interdisciplinary areas: European, Transnational and Global Governance; Global Economics; Europe in the World; and Cultural Pluralism.

The Programme also aims to contribute to the fostering of present and future generations of policy and decision makers through its unique executive training programme, the Academy of Global Governance, where theory and "real world" experience meet. At the Academy, executives, policy makers, diplomats, officials, private sector professionals and academics, have the opportunity to meet, share views and debate with leading academics, top-level officials, heads of international organisations and senior executives, on topical issues relating to governance.

For more information: http://globalgovernanceprogramme.eui.eu 


\begin{abstract}
Without the prospect of new treaty revisions, integration in the European Union is often believed to come at a standstill. However, recent research suggests that deepening integration still continues, albeit in more covert ways. The risk associated with such covert integration is that it is not mandated by the member states and may thus have a major backlash on the legitimacy of the European project. This paper argues that such fears may be unfounded. Building on prior insights of the principal-agent model in the context of European integration, we argue that any shift in the nexus of decision-making towards the supranational level is accompanied with the installation of control mechanisms. This takes the form of informal governance and increased oversight. The plausibility of this argument is probed on the EU's propensity to negotiate deep and comprehensive trade agreements. Insights are complemented from the Open-Skies agreement and the role of the European Central Bank during the Eurozone-crisis.
\end{abstract}

\title{
Keywords
}

Covert integration, principal-agent model, informal decision-making. 



\section{Introduction*}

Does covert integration in the European Union necessarily lead to a loss of legitimacy? Traditionally, integration takes place under the auspices of the member states through consecutive treaty reforms. Covert integration, by contrast, implies a shift in the nexus of decision-making "without explicitly being mandated by formal political actors" (Héritier, 2015, p.352). As such it increases the risk of political backlash in case decisions are not well received at home.

Traditionally, a transfer of authority to an international organisation is accompanied by the installation of control mechanisms to ensure the organisation acts in the interests of its national principals. Because covert integration occurs outside the formal decision-making arena, additional formal control mechanisms cannot be provided for. We argue that there are nonetheless alternative methods to ensure covert integration does not go unchecked. On the one hand, member states can turn to informal decision-making, while on the other procedural oversight or monitoring can also be enhanced. This paper explores whether covert integration in the EU coincides with the expansion of (informal) control, which may mitigate potential losses in legitimacy. Indeed, the deduction that control can still be enhanced through informal decision-making and procedural oversight does not imply that the potential for political backlash is automatically reduced. This depends to a large extent on the effectiveness of the installed control mechanisms, the assessment of which forms the second aspiration of this paper.

We probe the plausibility of our claims through three case studies. The central case explores the procedural changes that occurred in reaction to the European Commission's agenda of negotiating deep and comprehensive free trade agreements (DCFTAs). For such agreements, the Commission has to negotiate on regulatory issues for which the division of competencies is not always clear-cut. To uncover any changes in member state control, we look at the applied voting procedures within the Council as well as the role of Informal Technical Meetings (ITM) organised in the context of these negotiations. To analyse the effectiveness of these control mechanisms, we will reflect on the scope for legal contestation of the informal voting procedures applied and study the dynamics between member states and Commission within the ITMs. In addition, two peripheral cases are drawn from Héritier's original work: the growing competences of the ECB during the financial crisis, and the empowerment of the Commission in scrutinizing national noise regulations through the Open Skies Agreement (Héritier, 2015).

The paper is structured as follows. The first section overviews the link between delegation and control as established in the Principal-Agent model. It extends this logic to the notion of covert integration and formulates two hypothesis. The second section argues that the negotiation of DCFTAs by the Commission carries the potential for covert integration. The third section then presents a plausibility probe of the two hypotheses, as applied to the negotiations of DCFTAs. To broaden our exercise, we present data on the two peripheral cases in the fourth section. While somewhat speculative, this exercise may - ideally - motivate others to explore the linkages between informal means of control and covert integration. The cases provide support to our claim that political backlash from covert integration may be contained through informal control and increased monitoring (procedural oversight). In the concluding discussion we will touch upon the scope conditions that determine whether effective control is sufficient to ensure legitimate outcomes.

\footnotetext{
An earlier version of this paper was presented at the UCSIA workshop on Collective decision-making, 13\&14 November 2014 in Antwerp, Belgium. We would like to thank the attendees for their insightful comments and suggestions. We also would like to extend our gratitude to Hubert Zimmerman, Christine Neuhold and an anonymous reviewer for reading and commenting a previous draft of this paper.
} 


\section{Delegation and control: invariably linked?}

De Bièvre and Dur (2005: 1291) observed that in EU and US trade politics "the degree of control keeps pace with the scope of delegation". Analysing why the scope of delegation and control have developed in parallel in both EU and US trade policy making, they argue that after initial delegation the rising share of tradables has not reversed the scope of delegation but rather extended it. Because of electoral and political reasons however, principals made sure to maintain oversight and control over what the agent is doing. Indeed, trade discussions have come to touch ever more sensitive domestic policy issues, making the existing mechanisms for controlling the executive insufficient.

The observation that delegation and control coincide finds its origins in the congressional dominance school of the early '80s (McCubbins \& Schwartz, 1984; Weingast \& Moran, 1983). This school is based on the premise that whenever a task is delegated to a bureaucratic agency, the delegating party also installs control mechanisms to ensure the agency acts in its interests. ${ }^{1} \mathrm{~A}$ principal's assessment of the appropriate level of control is determined by the expected losses that might arise from deviant behaviour of the agent in the absence of such control (agency losses). More control comes at a price however, and the principal has to weigh these agency costs against the benefits from reduced agency losses. From this line of thinking, a link between the amount of delegation and the amount of congressional oversight was established:

"[...] legislators do not wash their hands of policy once delegated to the executive, rather, they oversee more intensely those issues on which they delegate the greatest amount of discretion." (Epstein \& O’Halloran, 1999).

The congressional dominance and runaway-bureaucracy schools in US politics find their European counterparts under the denominators of intergovernmentalism and supranationalism (Pollack, 1997). These approaches are the main players in the integrationist debate and each proposes a very different view on who has the final say about the pace and size of EU integration processes. As the integrationist discussion essentially revolves around power balances between the national member states and the supranational EU institutions, the link with principal-agent models is easily made. Consequently, the principal-agent model has been used for developing more nuanced understandings of the relationship between EU member states and EU institutions (Kassim \& Menon, 2003; Pollack, 1997).

Delegation as described in the principal-agent literature clearly aligns with the process of deepening integration defined by Héritier (2015: 352) as "(i) a transfer of policy-making competences to the higher level/supranational level; and/or (ii) the demandingness and detailedness of policy prescriptions issued by the supranational level." This delegation almost always takes place under the form of incomplete contracts. Principal and agent then debate on the true scope of the agreed delegation. The important roles played by the Commission and the European Court of Justice in interpreting this 'incompleteness' in favour of the European level has been identified by Héritier as one of the main sources of covert integration. It occurs outside the formal treaty scope and thus has not met explicit approval by the member states.

Reminiscent of the principal-agent logic of delegation and control sketched above, we can formulate the expectation that covert integration - when undesired - may also be accompanied by increased control. But what type of control can be exerted in a context of covert integration? Traditionally, a distinction in the principal-agent literature is often made between two forms of control: sanctions and oversight (monitoring) ${ }^{2}$. Sanctions can range from budget restrictions, restaffing in the case of (executive) agencies, increasing the stringency of voting procedures, the right to

1 In contrast, the runaway-bureaucracy school posits that bureaucratic agents are entirely unconstrained by their principals due to their informational advantage (Pollack, 1997).

2 The occurrence of covert integration -by its very definition- excludes a formal decision by the principals to delegate to a specific agent, this makes ex ante mechanisms of control (e.g. selection of the agent) difficult, if not impossible, to use. 
scrutinize, to re-appointing the executive in the case of legislators. Monitoring can be increased by heightening the frequency and plurality of oversight, and through reporting mechanisms.

Unlike the 'traditional' cases where delegation and control form a joint-decision, covert integration occurs by subterfuge, which hinders the simultaneous determination of the required control mechanism. Tightening control is, however, still possible within the existing framework when resorting to informal governance. In our reasoning, we follow Marijke Kleine's liberal theory of informal governance (Kleine, 2013). She defines informal governance as a deviation from the type of behaviour game theory would predict on the basis of the formal rules and procedures. According to her theory, informal governance arises in light of uncertainty. When member states fear that policy outcomes would result in domestic pressures that may compromise overall support to the whole EU project, it can be considered appropriate to deviate from formal procedures and accommodate the interests of the pressured member state. In the face of covert integration, we would therefore expect to see an increase in the use of such informal governance arrangements. Clearly, the occurrence of informal control is contingent on the member states' assessment of such integration being undesirable. If the principals deem further integration as beneficial to their own (material) interests, no additional control may be required. In this light, we formulated the following first hypothesis:

\section{H1: If covert integration takes place without the member states' support, we will observe an increased reliance on informal governance.}

One example of such arrangements is the applied voting procedure within the Council. While the treaty specifies that Qualified Majority Voting (QMV) is applicable, member states can - and often will - deviate from this procedure by deciding through consensus. Alternatively, member state noncompliance with national implementation of regulation can also be considered an instance of informal governance.

A second means for member states to heighten control in light of covert integration, is to increase the procedural mechanisms of oversight (Mccubbins, Noll, \& Weingast, 1987). Through increased monitoring, covert integration can be held in check or at least be subjected to member states' approval. Unlike the treaty provisions, administrative procedures can easily be adjusted. This can be attained through an increase in the frequency or formats through which Council working parties convene or through the creation of de novo monitoring committees. Hence, this paper presents the second hypothesis:

\section{H2: If covert integration takes place without the member states' support, we will observe more intense monitoring of the delegated task.}

In the following sections, we will probe the plausibility of these claims through three case- studies. The cases are selected based on the independent variables, i.e. the occurrence of covert integration and the lack of member state support thereof. Through these probes we hope to assess whether proper hypothesis-testing can be justified. The main case will be the EU's negotiation of deep and comprehensive trade agreements, a domain in which EU competence creep has frequently occurred and is often contested by the member states. The two peripheral cases are selected from the original work of Héritier (2015). These present a different set of patterns of covert integration, thereby increasing the external validity of our plausibility probe. ${ }^{3}$ The first peripheral case looks at the role of the ECB during the Euro-crisis and is an example of deepening integration through delegation to independent regulators. The ECB's interventions have caused an intense political debate; hence it is safe to assume the member states are less likely to have left covert integration unchecked. The second peripheral case is the implementation of the Open Skies Agreement, an example of deepening integration through international agreements. The subtle balance that had to be struck in the agreement

3 The additional advantage of drawing from her own original examples is the insurance we are indeed studying cases of covert integration, as conceptualized by Héritier. 
(see Woll, 2012) suggests that member states would have also been weary to delegate further authority without the installation of oversight or informal control. In our case-studies we rely on document analysis, case-law, in-depth interviews and public statements of involved policy officials.

\section{Covert integration through DCFTA negotiations}

The European Union is first and foremost a customs union. By consequence, the Common Commercial Policy (CCP) has been a large part of the integration process. Deepening integration under the CCP has frequently taken covert forms. A key factor in this process has been the growing scope of the issues considered as trade. This has often led to a heated debate between member states and the Commission; a debate in which the European Court of Justice (ECJ) has played a prominent role.

A first important case brought before the ECJ pertained to the UNCTAD International Natural Rubber Agreement of 1979. The member states questioned whether the negotiation of this agreement fell under the community's exclusive competency. The court ruling was in favour of the Commission and justified its decision in the following manner:

"It is therefore not possible to lay down, for article 113 of the EEC treaty, an interpretation the effect of which would be to restrict the common commercial policy to the use of instruments intended to have an effect only on the traditional aspects of external trade to the exclusion of more highly developed mechanisms such as appear in the agreement envisaged. A 'commercial policy' understood in that sense would be destined to become nugatory in the course of time." (ECJ, Opinion 1/78 §44).

In light of the observed expansion in the EU's trade agenda, this opinion could well be interpreted as opening the door to covert integration.

When the trade agenda did in fact expand later in the context of the GATT Uruguay Round, the Commission assumed it would fall under the EC's exclusive competency. The agenda encompassed trade in services and trade-related intellectual property rights. This was widely contested by the member states and led to another case being brought before the ECJ. The Commission asserted its competence prerogatives largely based on ECJ Opinion 1/78 and 1/75. The Court re-established the EU's exclusive competency on trade in goods, but interpreted trade in services and trade-related intellectual property rights as a mixed competency (ECJ, Opinion 1/94). The juxtaposition of both cases suggests that the ECJ's decision does not always lead to integration and that the changing nature of trade requires further specification of the incomplete contract. In the current, post-Lisbon era, the pendulum might swing again in the Commission's favour. Two recent decisions by the European Court of Justice resulted in an affirmation of the increased scope of the Union's exclusive competency: Daiichi Sankyo (intellectual property rights) and Conditional Access Convention (trade in services) (Larik, 2015).

Most of the cases brought before the ECJ were triggered by a trade negotiation that explored the boundaries of the treaty provisions. While the Court often played an important role in specifying the division of competencies between the national and European levels, member states also amended the treaties to this end (Niemann, 2011, 2013). The Treaty of Lisbon incorporated trade in services, traderelated intellectual property rights and foreign direct investment as part of the common commercial policy. Despite the Lisbon treaty clarifications, the EU's current pursuit of deep and comprehensive trade agreements has already sprung a new series of conflicts over competencies. It is not hard to see why: these agreements seek to address those impediments to trade we find behind-the-border. They concern mostly domestic regulations on product standards, schemes of state-support or what Alasdair Young and John Peterson called 'commercial trade policy' (Young and Peterson, 2006). They are also comprehensive, meaning these agreements seek to address the full scope of such barriers to trade, encompassing amongst others technical barriers to trade, sanitary and phyto-sanitary measures, intellectual property rights, investment and trade in services. 
The question that remains is whether we can conceive of these deep and comprehensive trade agreements as examples of covert integration. Covert integration - interpreted as a transfer of authority - is unlikely to occur through DCFTAs, as the treaty provisions specify that:

"The exercise of the competences conferred by this Article in the field of the common commercial policy shall not affect the delimitation of competences between the Union and the Member States, and shall not lead to harmonisation of legislative or regulatory provisions of the Member States in so far as the Treaties exclude such harmonisation." (Art. 207 TFEU).

By contrast, negotiations on DCFTAs may result in covert integration if interpreted as the degree of 'demandingness and detailedness of policy prescriptions issued by the supranational level' (Héritier, 2015). As an example, consider the negotiation of an alternative method to improve the accountability of investor-state dispute settlement (ISDS) in the Transatlantic Trade \& Investment Partnership. To open the negotiations, the Commission needs to receive a mandate from the Council. This negotiation mandate is inherently incomplete in order to grant the Commission sufficient discretion to complete the negotiation. With the mandate only stipulating the negotiation of an investment clause, most member states could not foresee that the ISDS mechanism would be completely remodelled through the negotiations. Because of the "deep and comprehensive" nature of contemporary trade negotiations, it is safe to argue that the 'demandingness' and 'detailedness' of the policy prescriptions have been significantly enhanced.

In other words, our central case is an example of the first pattern of covert integration as identified by Héritier, namely that the scope for deepening integration exists when vaguely formulated policy goals are specified by the executive or through court action during their implementation.

\section{Increased control in light of covert integration}

Recall from the first section that we suggested covert integration may be kept in check through informal means of control. Two such mechanisms were identified: an increase in the use of informal governance (H1) and more avid monitoring of the (more technical sides of the) trade negotiation (H2). We will probe the plausibility of these mechanisms arising as a reaction to the deep and comprehensive trade agenda, and assess their effectiveness in reducing the scope of political backlash.

\section{Increase in informal governance}

Ever since the 'Global Europe, Competing in the World' communication of the European Commission in 2006, the Commission has been bent on seeking deep and comprehensive market access abroad (Heron and Siles-Brügge, 2012). To accommodate the new member states, an extension of the exclusive competency was deemed necessary for the EU to meet this ambitious agenda. Functional rationales, along with social spill overs, thus explain the inclusion of trade in services and investment in the EU's exclusive competences in the Lisbon treaty (Niemann, 2013).

While the formal procedures might support the expectation of an increase in qualified majority voting in the Council, a different practice has become the norm. A Council official confirmed that "none of the current agreements which include everything under the sun require qualified majority [...]. There is little that can be decided as such under qualified majority." (Interview Council, 11 February 2013). Common accord is a reinforced unanimity rule where member states' abstention is not allowed. This practice has also extended to the adoption of a negotiating mandate. The member states insisted on adopting the negotiating mandate for the Transatlantic Trade and Investment Partnership under common accord. The reasoning of the member states was the following: because we do not know whether the resulting agreement might impinge on national competencies, it is best to assume the worst. The Commission, by contrast, supports the idea that a mandate is adopted under QMV, even though the applicable ratification procedure is determined by the content of the negotiated agreement. A Commission official expressed the concern that the practice of adopting the mandate 
under common accord may set prerogatives for the ratification procedure regardless of the agreement's content (Interview Commission, 16 April 2013).

The decision by the member states to deviate from qualified majority voting implies firmer control for the member states. In line with Kleine's liberal theory of informal governance, it is a decision motivated by the uncertainty over the potential effects of the resulting agreement. Yet, the decision to adopt a measure under common accord is supported by the (legal) assumption that the agreement is of mixed competency. This is an assumption that can (and will) be subject to debate. Such a debate will reveal whether this form of control will prove effective in containing potential backlash from covert integration.

At an outreach event in the context of the TTIP negotiations, a Commission official voiced the expectation that any new negotiation mandate will be adopted under common accord. The bigger issue was whether (and when) the Commission would question this practice (Brussels, 13 January 2015). Requesting an opinion of the European Court of Justice may result in a short-term gain, but it remains to be seen whether the Commission is eager to incur another 'Blair house blues'. ${ }^{4}$ If the Commission wants to obtain a mandate in the future, it needs to choose its battles wisely. In a setting of repeated games, cooperative behaviour becomes more likely and we may therefore expect (some) of these informal practices to remain uncontested and effective (Kerremans, 2004; Bó, 2005).

The newest case before the ECJ may be a case in point: on 30 October 2014, the Commission requested a clarification from the ECJ with respect to the competency over the investor-state dispute settlement (ISDS) clause included in the EU-Singapore DCFTA. The dispute revolves around the interpretation of the EU's exclusive competency over Foreign Direct Investments. According to the member states, foreign direct investment does not cover portfolio investment or investment protection. The inclusion of ISDS would make the agreement subject to mixed competency. Yet, in formulating its request for an opinion, the Commission specifically refrained from having the opinion apply to other cases like TTIP by stating: 'In case of the EU-US trade talks, for instance there will most likely be a number of elements that will require ratification by national parliaments' (European Commission 2014). It remains to be seen whether there are significant differences in the ISDS clauses of both agreements, but the case suggests the Commission accepts the member states' logic for the TTIP negotiations to secure (a chance at) a successful conclusion.

\section{Increased monitoring: the use of informal technical meetings}

While the incomplete nature of the negotiation mandate may allow the Commission some leeway, the distributive and politically sensitive nature of trade issues (in particular behind-the-border issues) implies that member states are keen on keeping some oversight on the negotiations. As argued by Héritier (2015), covert integration through delegation may cause political backlash when outcomes turn out to be less effective than initially expected. In trade negotiations member states keep control over the Commission throughout the negotiation process to monitor any covert integration trends and to prevent concentrated costs on their constituencies.

Such monitoring occurs through the Trade Policy Committee (TPC), which is a Council working party established by the Treaties (Art. 207(3) TFEU). The TPC has been accepted in the literature as a powerful ad locum - or procedural - control mechanism and in particular as a form of police patrol oversight (McCubbins and Schwartz, 1984; Delreux and Kerremans, 2010). It is a forum where member states can signal their policy positions and potential disagreement with the ongoing process, as well as monitor the Commission's actions in the external negotiations (Da Conceição, 2010; Adriaensen, in press). In various formats, this working party convenes almost twice a week.

4 Following the Commission's overreaching in the negotiation of the Blair House agreement in 1992, the member states (mostly France) were not eager to delegate much negotiating authority (Meunier, 2000). 
Over the last decade, a new coordination format has been gaining prominence in addition to the TPC: Informal Technical Meetings or ITMs. Similarly to the TPC, they are attended solely by Commission and member state officials. Because of their similar set-up, we conjecture that ITMs are the informal counterparts of the TPC: they work in the same way as a control mechanism but allow a more in-depth discussion about the intricacies of contemporary trade policy. With no formal agendas, invitations, minutes, attendance lists, register, reports or press briefings afterwards, ITMs are about as informal as it gets. Even the Commission expert groups - generally considered rather informal - are much more formalized in their set-up and reporting requirements. ITMs are the only forum in the EU trade set-up that combines this degree of informality with such a high meeting frequency and importance for the member states. Compared to the TPC, which discusses the broad negotiation strategy, ITMs discuss specific technical and regulatory issues more in depth, step-by-step and from a sectoral viewpoint (Interview Commission official, 19-11-2013; trade official, 12-02-2014). The Commission handles everything from organization, invitation, agenda-setting, logistics to chairing the meetings. But any Directorate-General or member state can ask for an ITM to be organized at any given time - a request that is almost always granted (Interview Commission official, 19-11-2013). This option allows member states with particular interests to create an extra forum to increase their leverage and monitoring powers over the Commission.

The number of ITMs has exploded after the launching of the 'Global Europe' policy and the beginning of DCFTAs (Interview trade official, 12-02-2014). It is expected that this number will continue to rise, an evolution already becoming clear in the case of TTIP negotiations, for which an ITM convened on regulatory cooperation, government procurement and intellectual property rights (Interview Commission official, 19-11-2013). In addition to the higher number of ITMs organized, we have also observed an increasing member state attendance rate. All member states now consider attending ITMs a conditio sine qua non if they want to keep informed on the negotiations: "a few years ago, it was sufficient to attend only the TPC. Now you cannot afford to do this anymore.'" (Interview trade official, 12-02-2014). ITMs have become one of the key information sources during trade negotiations for the member states.

The periodic convergence of the EU's deepening trade agenda and the rise of ITM frequency and attendance rate indicates that with trade negotiations reaching uncharted territory and becoming more complex, covert integration is lurking behind the corner and member states want to make sure they keep a foot in the door. The informal character makes for a particularly flexible negotiation framework, which allows for question-time and therefore a clear and common understanding of the issue at hand by all parties. It also gives the Commission a chance to explain the Brussels' way of thinking. Consequently, attending ITMs helps member states to formulate or adapt their official positions in the TPC and it also serves to make later discussions run more smoothly (Interview trade official, 01-02-2014). As was indicated by one respondent, "ITMs will never fundamentally change a member state's position, but little by little it can evolve. And this, you cannot achieve in the TPC because it is too formal." (Interview trade official, 12-02-2014; 24-02-2014). This influence goes in the opposite direction as well. Even though the EU position on a certain topic will never completely change, the Commission can incorporate a member state's opinion without any formal discussion on the matter.

This element of mutual influencing and policy learning has important implications because it plays a role in preventing political backlash. By explaining and substantiating the motives behind certain decisions it made in the external negotiations, the Commission can more easily convince the member states that it did, in fact, do the right thing. And because of the open and direct communication possible in ITMs, member states are confident that their voice is heard without any official record or without having to take into account - too much - the political aspects of the negotiations. As a consequence, the member states can judge the Commission's actions in a more informed way, and will therefore be more inclined to defend the outcome to their constituencies and legitimize the final trade agreement. 
The frequent use of ITMs and the increase of consensual decision-making suggest that member states - once aware of the risk of covert integration - picked up their monitoring of the Commission. This finding does not, however, suggest that control equals imposing the member state's position on the Commission, nor that it can prevent integration from taking place. But it does at least mitigate the scope for political backlash and illegitimate outcomes due to covert integration.

\section{An analysis of two complementary cases}

The above case has shown how covert integration is kept in check through increased control. Such control takes either the form of informal governance (H1) - defined as a deviation from the type of behaviour we would expect based on the formal rules - and increased monitoring (H2). While the application to the DCFTAs lends support to our claim, it remains questionable whether this observation is generalizable to other instances of covert integration. In this section, we wish to add credence to our earlier claims by looking at two additional cases. We have selected the cases to represent a wider diversity of patterns of covert integration. These are the role of the European Central Bank (ECB) during the Euro-crisis, as an instance of deepening integration through delegation to independent regulators, and the scrutiny of noise regulations through the Open Skies Agreement, as a case of deepening integration through international agreements.

\section{European Central Bank during the Eurocrisis}

Héritier refers to the increased role of the European Central Bank in face of the 2008-2009 Euro-crisis as an instance of deepening integration through delegation. Member states delegated the powers to specify the solution for their debt-ridden colleagues to the Commission and ECB. Drawing on the manner in which this delegation proceeded, one can argue that this constitutes a case of covert integration outside the formal treaty texts.

From bilateral loans between Greece and other member states, over a temporary European Financial Stabilization Facility (EFSF) and European Financial Stabilization Mechanism (EFSM), to the permanent European Stability Mechanism (ESM); the supranational nature of the delegation has gotten progressively stronger over time. The Treaty amendment required for the creation of this ESM very intentionally clarified that no new competences would be allocated to the EU: 'The Member States whose currency is the euro may establish a stability mechanism to be activated if indispensable to safeguard the stability of the euro area as a whole' (European Council, 2011, emphasis added). However, in the implementation of this stability mechanism it is the Commission, in liaison with the ECB and possibly the IMF, who negotiates, signs and monitors the memoranda of understanding required for allocating loans to member states in need (ESM Guideline on Loans).

So, while the responsibility of saving the Eurozone from immediate collapse is not de jure an EU competence, one can argue that once such a responsibility was allocated, the Commission and ECB had the de facto power to determine the degree of 'detailedness' and 'demandingness' of the policy prescriptions necessary to fulfil this task. The ECB also indicated its wish for supranational oversight until the ESM would eventually become a fully-fledged EU body:

"The ECB supports recourse to the Union method and would welcome that, with the benefit of the experience gained, the ESM would become a Union mechanism at an appropriate point in time. In the meantime, the ECB encourages that [...] Union institutions are granted a prominent role given their expertise and their focus on the collective Union interest." (European Central Bank, 2011)

In the lead up to the creation of the ESM as an officially intergovernmental fiscal body, we can detect a covert competence creep of the Commission and the ECB as central actors in the EU's response to the crisis. The member states, as official decision-makers of the stability mechanism delegated the task of detailing policy prescriptions and determining their demandingness (in this case the negotiation, signing and monitoring of the memoranda of understanding) to the Commission and the ECB, without 
specific delineations as regards the interpretation of this mandate. While implementing the Euro-crisis response, the Commission and ECB have made ample use of this discretion (See Beukers, 2013).

But does this also imply that such deepening integration is problematic for the democratic legitimacy of the EU? Maybe not, considering that the Eurogroup, ECFIN Council and European Council developed a parallel intergovernmental track of informal governance and monitoring to control the ongoing deepening integration. Puetter (2012) has reported a remarkably higher number of informal breakfast meetings of the ECFIN Council since the Euro-crisis. This increase was due to (a) the uncertainty of how to deal with such an unprecedented crisis and (b) the growing need for coordination on external representation in the G20 format. These informal, ministerial breakfast meetings also lasted up to three times longer than their formal counterparts, and were continued - also informally - on the lower deputy level afterwards.

Increased recourse to informal procedures has also been noted higher up in the Council hierarchy: "[...] direct bilateral communications (phone, video and short ad hoc meetings) related to economic governance issues between the 'heads' ahead of European Council meetings have increased over the last few years." (Puetter, 2012, p. 173-174, emphasis original). As was the case with the ECFIN Council, a clear distinction between formal and informal European Council meetings was advocated and informal meetings on the Euro-crisis were later institutionalized into 'Euro Summits' (Puetter, 2012). In addition, a new institutional procedure has arised, where the ECB President is invited to all informal intergovernmental meetings on economic governance - even ad hoc mini-summits between Heads of State and Government (Beukers, 2013).

Member states' choices for informal meeting formats that allow for a more deliberative coordination exercise in view of political uncertainty suggest firmer control over the implementation of the EU crisis policy instead of less. Moreover, the increased interaction between intergovernmental and supranational actors in these informal arenas indicates that the covert deepening integration coincides with increased monitoring efforts by the member states.

\section{The Open Skies Agreement}

The EU-US Open Skies Agreement is a transatlantic agreement that seeks to regulate international air traffic. According to Héritier, it led to covert integration through the inclusion of a clause which confers powers upon the Commission to monitor and scrutinize the imposition of noise restrictions around airports by national regulators. Such regulations often imply operational limitations for the air carriers such as a flight ban during the night. The US was concerned that many of these measures were more distorting than necessary and through international negotiations both partners agreed that a transparent and pre-determined process was to be followed to reduce such distortions. The Commission was to be in charge of monitoring and scrutinizing this process. The case serves as an example of 'deepening integration through external contracts' a pattern of covert integration that empowers supranational authorities through their capability to interpret vague provisions in agreements with external actors.

The aftermath of the Open Skies Agreement shows a reaction of the member states and European Parliament to re-establish control. The legislation to implement the discussed procedures in the Open Skies Agreement was tabled by the Commission in 2011 (European Commission, 2011). In the original proposal, (sub-) national regulators had to inform the Commission of any (proposed) restrictive measure six months in advance. The Commission could then assess conformity with the tabled regulation. In case the measure was deemed more restrictive than necessary, it held the power to suspend this regulation (European Commission, 2011, Art. 10).

The proposed legislation was drastically amended by both Council and European Parliament up to the point that the U.S. delegation felt the need to "reiterate(d) its concerns about [...] the proposed noise Regulation and suggest(ed) that it did not adequately develop a true right of scrutiny for the Commission." (US Department of State, 2013). Instead of the ability to suspend overtly distorting 
regulations, the Commission was ultimately only granted the power to inform the competent (sub-) national authorities if it found the process (not the decision!) to deviate from the regulation. Its de facto power was further reduced as the relevant competent authorities were given the option to take the Commission's opinion into account and were only obliged to inform the Commission of its intentions before implementing the measure. Additional changes to the original proposal for a regulation pertained to the use of delegated acts and the delay of the date it goes into effect. The proposal that was ultimately adopted by the European Parliament in April 2014 will go into effect mid-2016; six years after the protocol to the Open Skies Agreement was concluded. Throughout this period, the US delegation has repeatedly voiced complaints in the Joint Committee meetings of the Open Skies Agreement on the imposition of operating restrictions in general (US Department of State, 2012), the lack of transparency in Frankfurt's incentive programme to reduce noise (US Department of State, 2014) or the imposition of noise fees at Italian airports (US Department of State, 2013).

While the original agreement foresaw an empowerment of the Commission, member states effectively controlled such powers during the implementation phase. The main mechanism of control was informal governance in the form of non-compliance. The decision not to comply is an overt deviation from the practices we would expect on the basis of the formal rules. As such, it clearly fits the moniker of informal governance (Kleine, 2013, p.37).

\section{Concluding discussion}

Does covert integration increase the risk of political backlash and a potential loss of the EU's legitimacy? In this paper we have argued that while the threat is real, it should not be overly problematized. Member states as principals install control mechanisms to ensure the shift in power from the national to the supra-national level does not go unchecked.

Crucial in making this assertion is an appreciation of the many informal processes that characterize EU decision-making. As covert integration occurs outside the formal arena, a reinforced sanctioning mechanism cannot be provided. However, through informal governance practices member states retain a grasp over the decision-making process (H1). Moreover, an increase in - procedural - oversight or monitoring of the supranational agents' actions also helps to reduce the potential for political backlash $(\mathrm{H} 2)$. The cases discussed in this paper showed a notable increase in the use of control in response to covert integration. In the most extreme situation, such control has the equivalent effect of turning back the covert integration that triggered such heightened control.

We have argued that informal control does not automatically reduce the potential for political backlash: this depends to a large extent on the effectiveness of the installed control mechanisms. In most cases control is far from perfect. One reason may be that the principals (silently) approve the deepening integration and have chosen an appropriate level of (informal) control. In the context of politicized issues, this may be the preferred way in order to facilitate blame-shifting to the supranational level. Another reason could be that the integration occurred unnoticed in which case informal control mechanism can be installed much more quickly and with more flexibility once the covert integration becomes apparent. A third and final reason may be that the informal control mechanisms are ineffective or contested. These latter cases are the main reason why one should be concerned about the potential political backlash from covert integration.

The empirical examples discussed in this paper should at least give an indication that covert integration does not necessarily passes by unnoticed by those that we have labelled as the principals (the EU member states), and that these actors can and do develop their own tools outside of the formal arrangements to keep instances of covert integration in check. Whether or not these tools can also be considered as legitimate largely depends on the observer's conception of legitimacy.

If one considers the member state governments - and their interests as aggregated in the Council of ministers - as the legitimate representation of the EU public at large, then informal control of covert 
integration by these governments can be considered a way of preventing political backlash. This type of "collective redefinition of sovereignty" and "peer review process" has the potential of ensuring a degree of input legitimacy at the national domestic level (Lewis, 2003, p. 1014). As Kleine argues: "informal governance serves to include in the political process the voices of those actors who are most affected by a decision at the EU level [and] thus mitigates excessive distributive effects [...]"(Kleine, 2013, p. 7). As informality enhances the potential for problem-solving and finding common accord based on rational and expertise-based arguments, informal control over covert integration can also enhance what is considered output legitimacy of policies (Curtin \& Meijer, 2006; Haverland \& Liefferink, 2012; Lewis, 2003, 2010; Niemann, 2006; Puetter, 2003; Verdun, 1999). On the other hand, because informality also has the effect of insulating decision-making from outsiders, promoting selective participation and depoliticizing the discussion, it does not exactly enhance the potential for gauging political accountability during decision-making (Eberlein \& Grande, 2005; Lewis, 2003; Puetter, 2003).

Future research may corroborate the provisional findings of this paper, elaborate the scope conditions under which covert integration is accompanied by informal control and study the overall impact of covert integration on EU legitimacy. 


\section{References}

\section{A. Primary Sources}

European Central Bank, 2011. 'Opinion of the European Central Bank of 17 March 2011 on a draft European Council Decision amending Article 136 of the Treaty on the functioning of the European Union with regard to a stability mechanism for member states whose currency is the euro', Official Journal of the European Union, C 140/8-11, 11 May 2011.

European Commission, 2010a. 'Communication from the president to the commission. Framework for commission expert groups: horizontal rules and public register', C(2010) 7649 final. Available at: http://ec.europa.eu/dgs/internal_market/docs/expert_groups/C2010_7649_en.pdf [Accessed 21 January 2016].

European Commission, 2010b. 'Commission staff working document. Accompanying document to the communication from the president to the commission. Framework for commission expert groups: horizontal rules and public register', $\operatorname{SEC}(2010) 1360$ final. Available at: http://ec.europa.eu/dgs/internal_market/docs/expert_groups/SEC_2010_1360_en.pdf [Accessed 21 January 2016].

European Commission, 2011. Proposal for a regulation of the European Parliament and of the Council on the establishment of rules and procedures with regard to the introduction of noise-related operating restrictions at Union airports within a balanced approach and repealing directive 2002/30/EC of the European Parliament and of the council noise-related operating restrictions at Union airports: rules and procedures', COM (2011) 828 - Procedure 2011/0398/COD.

European Commission, 2014. 'Press Release: Singapore: The Commission to Request a Court of Justice Opinion on the trade deal'. Brussels, 30 October 2014. Available at: http://europa.eu/rapid/press-release_IP-14-1235_en.htm [Accessed 31 January 2016].

European Council, 2011. 'European Council Decision of 25 March 2011 amending Article 136 of the Treaty on the functioning of the European Union with regard to a stability mechanism for member states whose currency is the euro', Official Journal of the European Union, L 91/1-2, 6 April 2011.

Opinion 1/94. Competence of the Community to conclude international agreements concerning services and the protection of intellectual property - Article 228 (6) of the EC Treaty [1994] ECR I 05267.

Opinion 1/78. Opinion given pursuant to the second subparagraph of Article 228(1) of the EEC Treaty - International Agreement on Natural Rubber [1979] ECR - 02871.

Opinion 1/75. Opinion given purusant to Article 228 (1) of the EEC Treaty [1975] ECR-01355

U.S. Department of State, 2012. Eleventh meeting of the U.S.-EU Joint Committee: record of meeting on May 30, 2012. Available at: http://www.state.gov/documents/organization/206057.pdf [Accessed 31 January 2016]

U.S. Department of State, 2013. Thirteenth meeting of the U.S.-EU Joint Committee: record of meeting on June 5, 2013. Available at: http://www.state.gov/e/eb/rls/othr/ata/e/eu/220539.htm [Accessed 21 January 2016].

U.S. Department of State, 2014. Fourteenth Meeting of the U.S.-EU Joint Committee: Record of Meeting on January 8, 2014. Available at: http://www.state.gov/e/eb/rls/othr/ata/e/eu/227943.htm [Accessed 21 January 2016].

Interview council official (Brussels, 11-02-2013). Interview on Commission-Council interaction in trade policy. [Interviewer Johan Adriaensen]. 
Interview commission official (Brussels, 16-04-2013). Interview on Commission-Council interaction in trade policy. [Interviewer Johan Adriaensen].

Interview commission official (Brussels, 19-11-2013). Interview on informal technical meetings. [Interviewer Evelyn Coremans].

Interview national trade official (Brussels, 01-02-2014). Interview on informal technical meetings. [Interviewer Evelyn Coremans].

Interview national trade official (Brussels, 12-02-2014). Interview on informal technical meetings. [Interviewer Evelyn Coremans].

Interview national trade official (Brussels, 24-02-2014). Interview on informal technical meetings. [Interviewer Evelyn Coremans].

\section{B. Secondary Sources}

Adriaensen, J., 2016. National Administrations in EU Trade Policy: Maintaining the capacity to control. Houndmills: Palgrave MacMillan.

Beukers, T., 2013. The new ECB and its relationship with the Eurozone member states: between central bank independence and central bank intervention. Common Market Law Review, 50, pp.1579-1620.

Bó, P. D., 2005. Cooperation under the shadow of the future: experimental evidence from infinitely repeated games. The American Economic Review, 95(5), pp. 1591-1604.

Curtin, D., \& Meijer, A. (2006). Does Transparancy Strengthen Legitimacy? Information Policy, 11, $109-122$.

Da Conceição, E., 2010. Who controls whom? Dynamics of power delegation and agency losses in EU trade politics. Journal of Common Market Studies, 48(4), pp.1107-1126.

Damro, C., 2007. EU delegation and agency in international trade negotiations: a cautionary comparison. JCMS: Journal of Common Market Studies, 45(4), pp.883-903.

De Bièvre, D. and Dür, A., 2005. Constituency interests and delegation in European and American trade policy. Comparative Political Studies, 38(10), pp.1271-1296.

Delreux, T. and Kerremans, B., 2010. How agents weaken their principals' incentives to control: the case of EU negotiators and EU member states in multilateral negotiations. Journal of European Integration, 32(4), pp.357-374.

Eberlein, B., \& Grande, E. (2005). Beyond delegation: transnational regulatory regimes and the eu regulatory state. Journal of European Public Policy, 12(1), 89-112.

Epstein, D. and O'Halloran, S., 1999. Delegating powers: a transaction cost politics approach to policy making under separate powers. Cambridge: Cambridge University Press.

Haverland, M., \& Liefferink, D. (2012). Member State interest articulation in the Commission phase. Institutional pre-conditions for influencing "Brussels." Journal of European Public Policy, 19(2), 179-197.

Héritier, A., 2015. Covert integration in the European Union. In: Richardson J. and S. Mazey (eds), European Union: power and policy-making. Fourth edition, New York: Routledge, pp. 351-369.

Heron, T. and Siles-Brügge, G., 2012. Competitive liberalization and the "global Europe" services and investment agenda: locating the commercial drivers of the EU-ACP Economic Partnership Agreements. JCMS: Journal of Common Market Studies, 50(2), pp.250-266. 
Kassim, H. and Menon, A., 2003. The principal-agent approach and the study of the European Union: promise unfulfilled? Journal of European Public Policy, 10(1), pp.121-139.

Kerremans, B. (2004). What Went Wrong in Cancun? A Principal-Agent View on the EU's Rationale Towards the Doha Development Round. European Foreign Affairs Review, 9(3), 363-393.

Kerremans, B., 2006. Proactive policy entrepreneur or risk minimizer? A principal-agent interpretation of the EU's role in the WTO. In: O. Egström and M. Smith, eds. 2006. The European Union's roles in international politics: concepts and analysis. Abingdon: Routledge. pp.172-188.

Kleine, M., 2013. Informal governance in the European Union. How governments make international organisations work. Ithaca: Cornell University Press.

Larik, J., 2015. No mixed feelings: the post-Lisbon common commercial policy in Daiichi Sankyo and commission v. council (Conditional Access Convention). Common Market Law Review, 52(3), pp. 779-800.

Lewis, J. (2003). Informal integration and the supranational construction of the Council. Journal of European Public Policy, 10(6), 996-1019.

Lewis, J. (2010). How institutional environments facilitate co-operative negotiation styles in EU decision-making. Journal of European Public Policy, 17(5), 648-664.

McCubbins, M.D. and Schwartz, T., 1984. Congressional oversight overlooked: police patrols versus fire alarms. American Journal of Political Science, 28(1), pp.165-179. Available at: http://jstor.org [Accessed 21 January 2016].

McCubbins, M.D., Noll, R.G. and Weingast, B.R., 1987. Administrative procedures as instruments of political control. Journal of Law, Economics \& Organization, 3(2), pp.243-277.

Meunier, S., 2000. What single voice? European institutions and EU-U.S. trade negotiations. International Organization, 54(1), pp.103-135. doi:10.1162/002081800551136.

Niemann, A. (2006). Beyond Problem-Solving and Bargaining: Genuine Debate in EU External Trade Negotiations. International Negotiation, 11(3), 467-497.

Niemann, A., 2011. Conceptualising common commercial policy treaty revision: explaining stagnancy and dynamics from the Amsterdam IGC to the Treaty of Lisbon. European Integration Online Papers (EIoP), 15(6), pp.1-52.

Niemann, A., 2013. EU external trade and the Treaty of Lisbon: a revised neofunctionalist approach. Journal of Contemporary European Research, 9(4), pp.633-658.

Pollack, M., 1997. Delegation, agency, and agenda setting in the European Community. International Organization, 51(1), pp.99-134.

Puetter, U. (2003). Informal Circles of Ministers: A Way Out of the EU's Institutional Dilemmas? European Law Journal, 9(1), pp. 109-124.

Puetter, U., 2012. Europe's deliberative intergovernmentalism: the role of the Council and European Council in EU economic governance. Journal of European Public Policy, 19(2), pp.161-178.

Verdun, A. (1999). The role of the Delors Committee in the creation of EMU: an epistemic community? Journal of European Public Policy, 6(2), pp.308-328.

Weingast, B.R. and Moran, M.J., 1983. Bureaucratic discretion or congressional control? Regulatory policymaking by the Federal Trade Commission. Journal of Political Economy, 91(5), pp.765-800.

Woll, C. (2012). Open skies, closed markets: Future games in the negotiation of international air transport. Review of International Political Economy, 19(5), pp.918-941. 


\section{Controlling Covert Integration in EU Politics}

Young, A.R. and Peterson, J., 2006. The EU and the new trade politics. Journal of European Public Policy, 13(6), pp.795-814. 


\section{Author contacts:}

\section{Johan Adriaensen}

Center for European Research in Maastricht (CERiM)

Maastricht University

Grote Gracht 90-92, 6211 SZ Maastricht, the Netherlands

Email: j.adriaensen@maastrichtuniversity.nl

\section{Evelyn Coremans}

Leuven InterNational and European Studies (LINES)

KU Leuven

Parkstraat 45 box 3602, 3000 Leuven, Belgium

Email: evelyn.coremans@ @soc.kuleuven.be 